\title{
Integrative activity of a point of sale and the product dissemination with augmented reality
}

\section{Actividad integradora de un punto de venta y la difusión de productos con realidad aumentada}

MORA-LUMBRERAS, Marva Angélica*†, SÁNCHEZ-SANCHEZ, Norma and SANCHEZ-PÉREZ Carolina Rocío

Universidad Autónoma de Tlaxcala, Faculty of Basic Sciences, Engineering and Technology

ID $1^{\text {st }}$ Autor: Marva Angélica, Mora-Lumbreras / ORC ID: 0000-0001-6505-2205, arXiv Author ID: marvaml, CVU CONACYT ID: 176815

ID $1^{\text {st }}$ Coautor: Norma, Sánchez-Sánchez / ORC ID: 0000-0002-9991-9206, Researcher ID Thomson: T-3524-2018, arXiv Author ID: nsansan

ID $2^{\text {nd }}$ Coautor: Carolina Rocío, Sánchez-Pérez / ORC ID: 0000-0002-1695-4429, Researcher ID Thomson: W-7166-2019, arXiv Author ID: krlinasp, CVU CONACYT ID: 163716

DOI: $10.35429 / J H R T .2019 .15 .5 .9 .17$

Received: March 30, 2019; Accepted: June 20, 2019

\section{Abstract}

An Integrative Activity uses the skills and knowledge provided in various subjects to solve practical problems, with an individual and/ or group approach. Specifically in this article we work on a Point of Sale system and the Diffusion of Products with Augmented Reality, developed over three semesters and involving courses of Software Engineering, Computer Human Interaction, Design of Virtual Environments and Computing for Mobile Devices. The activity applies knowledge of software development models, usability, 3D modeling, augmented reality and development of web applications for mobile devices. At the end of this activity, the student has managed to develop complete software, from planning until testing phases.

3D Design, Web Development, Mobile Devices, Augmented Reality

\section{Resumen}

En una Actividad Integradora se utilizan las habilidades y conocimientos desarrollados en diversas materias para la resolución de problemas prácticos, con un enfoque individual y/o grupal. Específicamente en este artículo se trabaja un sistema de Punto de Venta y la Difusión de Productos con Realidad Aumentada, el cual fue desarrollado a lo largo de tres semestres y en el que se involucran materias de Ingeniería de Software, Interacción Humano Computadora, Diseño de Ambientes Virtuales y Cómputo para Dispositivos Móviles. Para la actividad se aplican conocimientos de modelos de desarrollo de software, usabilidad, modelado 3D, Realidad Aumentada y desarrollo de aplicaciones web para dispositivos móviles. Al final de esta actividad el estudiante ha logrado desarrollar un software completo, desde las fases de planeación hasta las pruebas.

Diseño 3D, Desarrollo Web, Dispositivos Móviles, Realidad Aumentada

Citation: MORA-LUMBRERAS, Marva Angélica, SÁNCHEZ-SANCHEZ, Norma and SANCHEZ-PÉREZ Carolina Rocío. Integrative activity of a point of sale and the product dissemination with augmented reality. Journal of Human Resources Training. 2019, 5-15: 9-17

*Correspondence to Author (marva.mora@gmail.com)

$\dagger$ Researcher contributing first Author 


\section{Introduction}

The Integrative Activity becomes the axis of the curricular integration and the contribution to the expected generic competences of the students who study a curriculum based on the Humanistic Model based on Competences (MHIC) of the Autonomous University of Tlaxcala (UAT).

The Integrative Activity implies both the formation of student work teams and collegiate groups of teachers per semester whose main purpose is the Integration of knowledge of the different Learning Units in an interdisciplinary work.

In the educational program of Computer Engineering of the UAT, it allows the development of an interdisciplinary work, due to the great variety of software development that is required, an Integrating Activity in addition to combining knowledge to solve a specific problem allows to have one more product complete, as well as having a well planned development process.

The comprehensive preparation of higher education students in the area of computing generally involves one or more Software Engineering courses, where these courses seek to cover the classic software development life cycle with the requirements analysis, design phases, construction, tests and sometimes implementation and maintenance, with the aim of instructing students in the application of good practices throughout the development process.

Although the development phases are clearly defined by the generic life cycle, not so, what set of practices should be included in a course, nor the order in which they should be introduced. The CMMi model for development defines a set of specific practices aimed at the development of software products, specifically the model at level 2 defines practices for requirements management, project planning, monitoring and control, quality assurance, measurement and analysis, configuration management and monitoring with suppliers.

This project presents an Integrative Activity that uses the knowledge developed in various learning units for the resolution of a Point of Sale system and the Diffusion of Products with Augmented Reality in which the following learning units are involved:
Software Engineering integrating CMMi model practices, Computer Human Interaction Paradigms, Design of Virtual Environments and Computing for Mobile Devices.

In section 2 three related works are presented, in section 3 the theoretical framework that covers the topics of Integrative Activity, CMMi, 3D Modeling, Augmented Reality and Usability is described, in Section 4 the Work Methodology is described, in the section 5 describes the contributions of each learning unit to the Integrative Activity project, in section 6 presents a discussion of the work done, in section 7 the acknowledgments to the work team are mentioned, in section 8 the conclusions and in section 9 the References are listed.

\section{Related jobs}

\section{The Integrative Teaching Tasks Within the Structure of the Study Activity}

In this work a study of the importance of integrative teaching tasks was carried out, they sought to highlight some regularities to facilitate the design, execution and control of tasks. Finally, they realized that the guiding character, integrative approach and systematization of the contents, systemic approach to the integrative teaching task, linking education with life, attention to diversity, group character of teaching tasks and systematic, collective character and dynamic methodological work are essential for the development of a complete work (Mass et al, 2010)

\section{Posing Problem Situations as an Integrative Strategy in the Teaching of Science and Technology}

This paper presents the results of the implementation of an interdisciplinary teaching strategy, in the technology curriculum space. It includes topics from other curricular spaces such as natural sciences (physics, chemistry and biology), mathematics and geography, from the third cycle of Basic General Education (EGB). This proposal tries to favor the integration of conceptual, procedural and attitudinal contents, taking as its axis the problem situations, whose approach and solution implies knowledge related to housing, food, energy, environmental pollution, among others (Vázquez, 2004). 


\section{Methodological Activities for the Preparation of Human Morphophysiology Facilitators in the Development of Integrative Teaching Tasks}

In this article, the proposal of a system of methodological activities aimed at improving the preparation of the Human Morphophysiology teacher for the development and application of integrative teaching tasks was set as an objective. During their development they carried out a qualitative transversal research, where the theoretical-synthetic, historical-logical, the inductive-deductive theoretical methods and the system approach were used, as well as the Expert Criteria method to validate the proposal of the methodological activities system working with a population consisting of the 10 facilitating teachers who attended the preparatory meetings that took place at the headquarters, the University of Medical Sciences. Finding as a conclusion that the development of the proposed methodological activity system can improve the preparation of teachers of Human Morphophysiology for the development of integrative teaching tasks thus achieving a better performance of their teachers (Peña et al, 2011).

\section{Theoretical framework}

Below are the topics involved in this article and that are relevant to mention: Integrative Activity, CMMi, Usability, 3D Modeling and Augmented Reality.

\section{Integrative activity}

An Integrative Activity is a system of actions that relate the skills and knowledge in the contents provided according to the objectives, not in isolation, but in harmony and well founded scientifically, which lead to greater independence and resolution in students to the problems of practice, with an individual and group approach (Pérez, 2006).

The Integrative Activity constitutes an alternative to face the challenge of the integration of the contents, to achieve it requires the cooperation of teachers and students.

\section{CMMi}

With the objective of minimizing risks in the development of projects, managing changes in requirements effectively and maintaining a quality approach meeting the expectations of customers, the CMMi-Dev level 2 maturity model is taught in the Engineering Degree. The process areas considered at this level are (CMMi, 2010), (Chrissis, 2009):
1. Requirements Management
2. Project planning
3. Project monitoring and control
4. Process and product quality assurance
5. Measurement and Analysis
6. Configuration Management
7. Monitoring of agreements with suppliers

\section{D modeling}

3D modeling consists of sculpting 3D objects on the computer using a 3D mouse and keyboard, using 3D computer programs that handle surfaces and solids. There are many skills that a modeler must acquire and control: drawing, painting, lighting, texture application. It is difficult to find another discipline that requires such a wide range of creativity, knowledge and technical ability. (Ratner, 2005)

\section{Augmented reality}

The Augmented Reality RA allows the user to see the real world, in which virtual objects are superimposed, such as 2D animations, 3D objects, audio and / or video (Heras, 2007). Mobile devices have a great impact today, because it is very easy to run in this type of devices, Augmented Reality applications in real time, either by geographical location of the user or with markers with information stored on the device (Fombona, 2012).

\section{Usability}

Usability handles two main components: one refers to the functional aspect of the system and another to how users can use that functionality. The main factors that should be considered when talking about usability are the ease of learning, the effectiveness of use and the satisfaction with which people are able to perform their tasks when using the product, factors that rest on the foundations of the design centered on the user (Preece, 1994). 


\section{Work methodology}

Initially, it was decided to work the Integrative Activity on a Point of Sale, taking the Software Engineering Unit as an Axis Learning Unit, which is covered in three semesters and where the CMMi model is reviewed under the cascade method. During the fourth, fifth and sixth semesters of the Computer Engineering education program, the CMMi model practices are implemented to realize a Point of Sale, see Figure 1.

\begin{tabular}{|c|c|c|}
\hline $\begin{array}{c}\text { Software } \\
\text { Engineering I }\end{array}$ & $\begin{array}{c}\text { Software } \\
\text { Engineering II }\end{array}$ & $\begin{array}{c}\text { Software } \\
\text { Engineering III }\end{array}$ \\
\hline & $\begin{array}{l}\text { Computer Human } \\
\text { Interaction } \\
\text { Paradigms }\end{array}$ & $\begin{array}{l}\text { Design of Virtual } \\
\text { Environments }\end{array}$ \\
\hline & & $\begin{array}{l}\text { Mobile Device } \\
\text { Computing }\end{array}$ \\
\hline Fourth semester & Fifth semester & Sixth semester \\
\hline
\end{tabular}

Figure 1 Learning Units considered for the Point of Sale Integrative Activity

In the Computer Human Interaction Paradigm Learning Unit seen in the fifth semester, we work with the usability of the software and a set of usability tests are carried out in order to make the software intuitive and easy to use.

During the Virtual Environments Design Learning Unit, work begins with the dissemination of the product, making 3D models of the products of the Point of Sale.

Finally, the Augmented Reality works in the Computer Learning Unit for Mobile Devices, using as markers the catalog of products of the Point of Sale, as well as the 3D models made in the Learning Unit of Design of virtual Environments.

\section{Developing}

\section{Software Engineering}

INPUT In the fourth semester the student makes a series of documents to cover the planning phases and requirements. In the fifth semester the analysis and design is carried out, including the UML diagrams that describe the logical design of the system, as well as the construction of the system aligned to the proposed design. Finally, in the sixth semester, the integration and testing, closure and implementation phases are considered.

During the fourth semester students identify an opportunity to develop a system, in this case a Point of Sale developed for a company dedicated to the sale of tourist packages is presented, where the objective of the system is to show information about destinations and packages tourism, in order to facilitate access, purchase and dissemination of trips to the different states of the Mexican Republic.

A set of specific practices of the CMMIDev 2 model were integrated into its requirements management process area, covering the practices of: 1 . Understanding the requirements, 2. Obtaining commitment to the requirements, 3. Managing changes to the requirements, 4. Maintain bidirectional traceability of requirements 5 . Ensure alignment between work products and requirements. In this case, during the development of the requirements phase, the work artifacts listed in Figure 2 are obtained, which evidenced the fulfillment of the practices

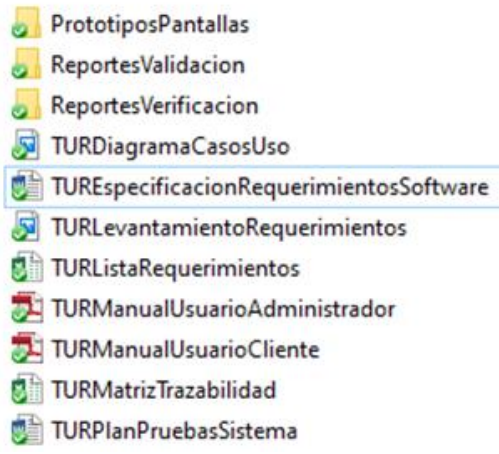

Figure 2 Artifacts developed in the requirements analysis phase

In the case of the Project Planning process area, students covered 3 specific goals with their corresponding practices: 
Goal 1. Establish estimates, involving the practices of: 1. Estimate the scope of the project, 2. Establish estimates of work product and task attributes, 3. Define the project life cycle phases, 4. Estimate effort and cost . Goal 2. Develop the project plan, in general the practices of: 1 . Establish the budget and schedule, 2. Identify project risks, 3. Manage data plan, 4. Plan project resources, 5. Plan necessary skills and knowledge, 6. Plan stakeholder involvement, 7 Establish project plan. Goal 3. Obtain commitment to the plan, including the practices of: 1. Review plans that affect the project, 2 . Reconcile work and resource levels, 3. Obtain commitment to the plan.

During the project planning, the Project Plan artifact is established considering the indicated practices, in Figure 2 a sample of estimation tool is added which complies with three model practices.

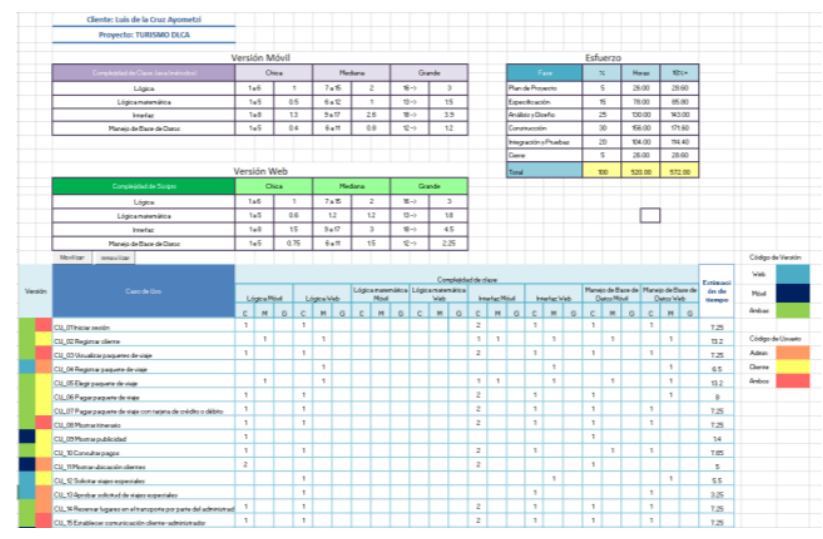

Figure 2 Project Estimate

In the course of the fifth semester the generated artifacts contemplate the analysis and logical design of the system, as shown in Figure 3. It is important to indicate that as part of the integrating activity the students obtain feedback from the Computer Human Interaction Paradigms Learning Unit and with this the analysis and design document is detailed, linking the knowledge acquired by both learning units. It is also in the construction phase where activities related to development and quality assurance activities are carried out, such as the integration of peer reviews and quality audits to the project and the process.

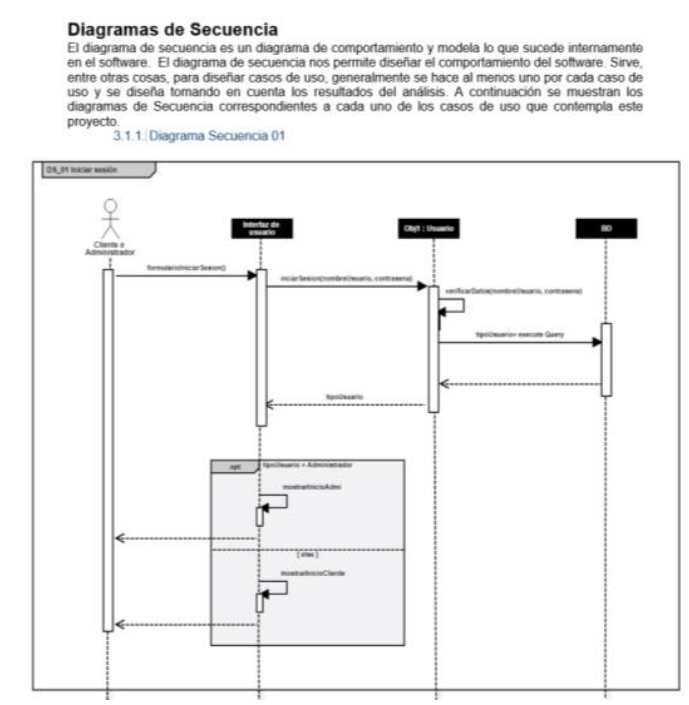

Figure 3 Artifacts generated in the design phase

Finally, in the sixth semester, the development of the system is concluded, through formal tests and the implementation of the system. Figure 4 shows part of the test plan.

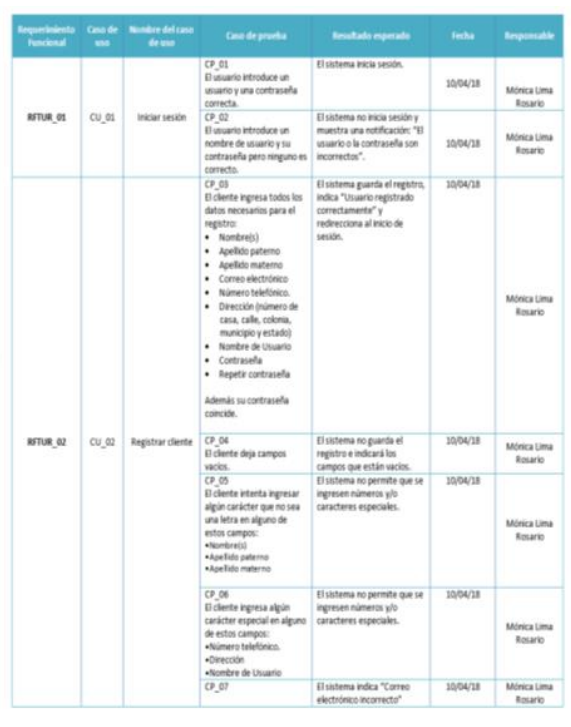

Figure 4 System test plan

It is important to indicate that in all semesters practices of quality assurance of the process and of the product, measurement and analysis, monitoring and control of the project, and configuration management were integrated; Figure 5 shows an example of the audit application to the project. 


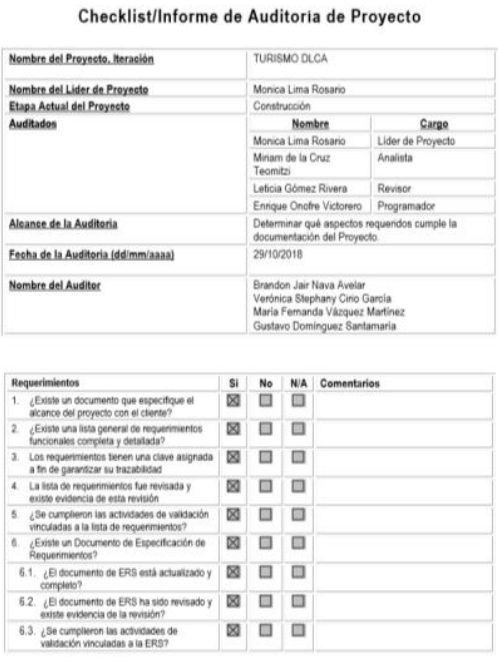

Figure 5 Project Audit Report

\section{Computer Human Interaction Paradigms}

INPUT: Design and implementation of project software interfaces and usability tests.

Below is the Point of Sale developed for a company dedicated to the sale of tourist packages. The Point of Sale was divided in view of the client and the administrator, where the client is the person who is looking for a touristic tour and the administrator is a staff of the Travel Agency, owner of the software.

Figure 6 shows the main interface of the Tourism Point of Sale project.

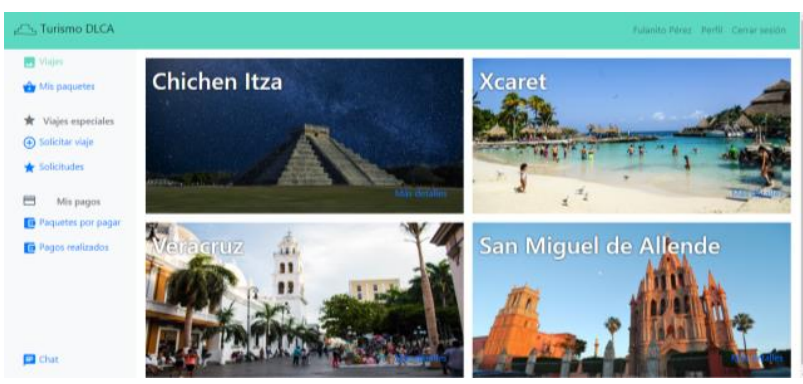

Figure 6 Main interface of the Tourism Point of Sale project

An interface for the Point of Sale administrator is shown in Figure 7

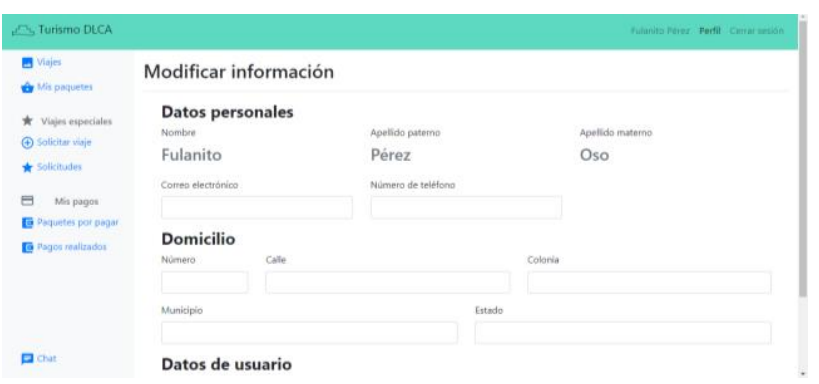

Figure 7 Point of Sale administrator interface
Figure 8 shows the interface worked for the client that seeks to make a tourist trip.

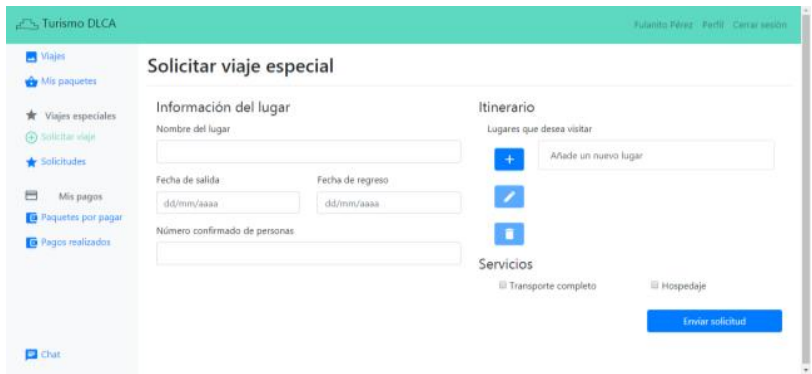

Figure 8 Client interface

Finally, usability tests were performed in the same room, as peer tests and focused on:

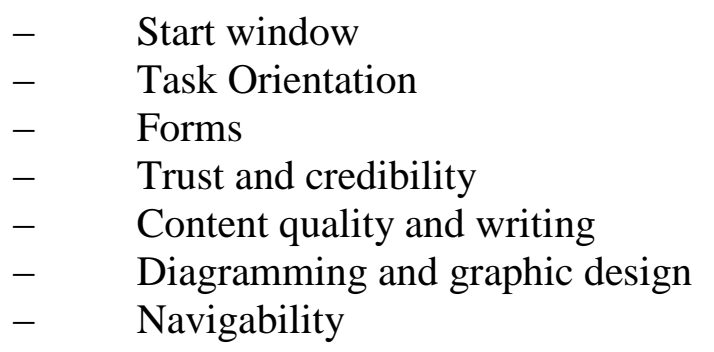

Which are complete to measure the usability of a product.

\section{Design of Virtual Environments}

INPUT: Material selection for 3D modeling, according to the Point of Sale implemented.

During the exercise of the Integrative Activity of the Tourism Point of Sale, there were problems in selecting the products of the project, because its sales product are trips, so it was decided to model products related to a trip.

Figure 9 shows a coconut with umbrella and straw, it was decided to include this object because it is one of the most characteristic on a walk to the beach.

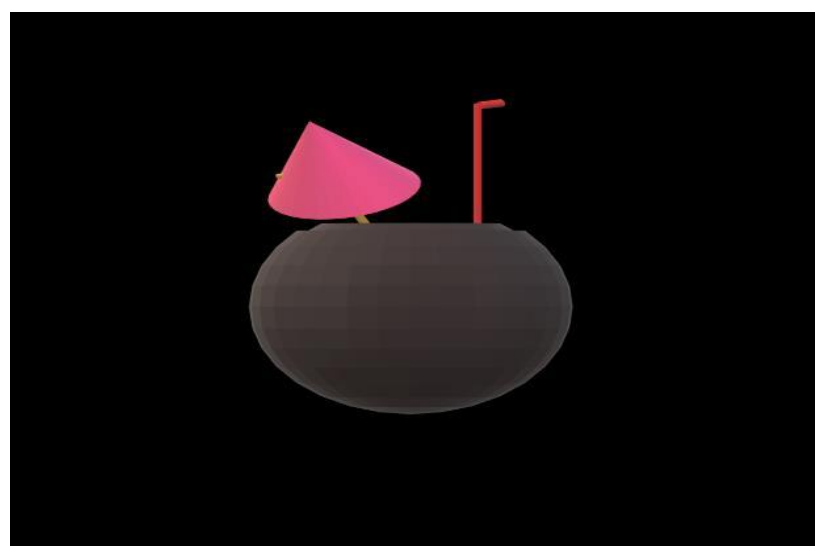

Figure 9 Coconut with umbrella

MORA-LUMBRERAS, Marva Angélica, SÁNCHEZ-SANCHEZ, Norma and SANCHEZ-PÉREZ Carolina Rocío. Integrative activity of a point of sale and the product dissemination with augmented reality. Journal of Human Resources Training. 2019 
Figure 10 shows a slide, chosen because many of the trips organized by the company usually have as a common feature the realization of aquatic activities, such as visits to the sea, or to recreational parks.

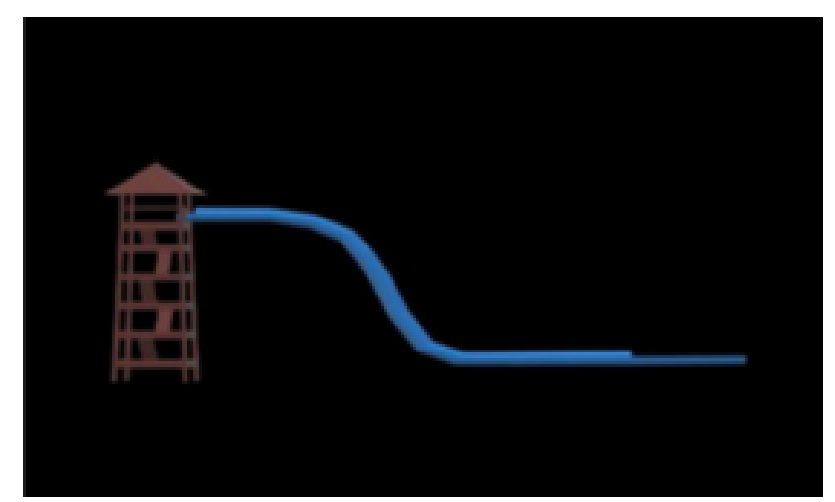

Figure 10 Slide

Figure 11 shows a pyramid, it was decided to model the pyramid of Chichen Itza because some of the tourist packages are towards this tourist destination.

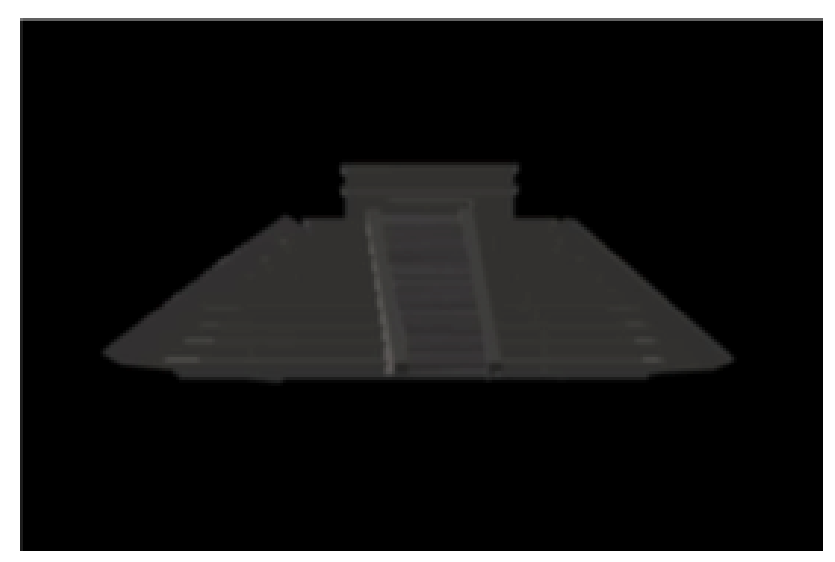

Figure 11 Pyramid

\section{Computing for Mobile Devices}

INPUT: Generate an APK for mobile devices with 3D models and markers of the Tourism Point of Sale products.

As part of the Integrative Activity, students made an Augmented Reality application for Android mobile devices using Vuforia and Unity.

On the Vuforia page, the database with the product markers was generated, for which good contrast images of the objects that were to be included in the Point of Sale product catalog were used. As shown in Figure 12.

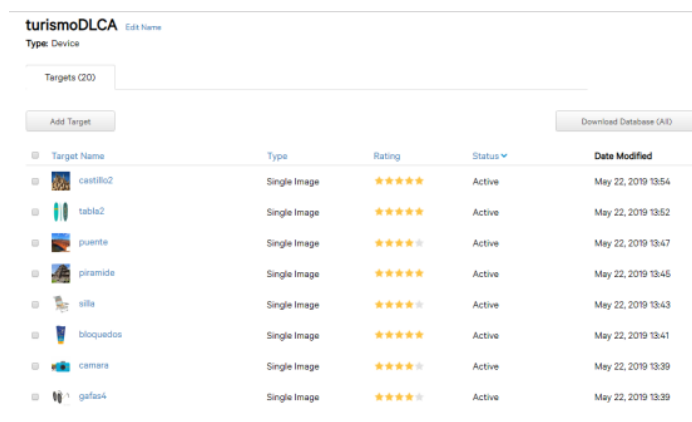

Figure 12 Database of markers in Vuforia

A project was created in Unity, where the use of Vuforia Augmented Reality was activated and the database with the markers was imported.

The next thing was to assign to each marker of the database the object created in 3D, which were modeled in the learning unit of Design of Virtual Environments. Figure 13 shows the process.

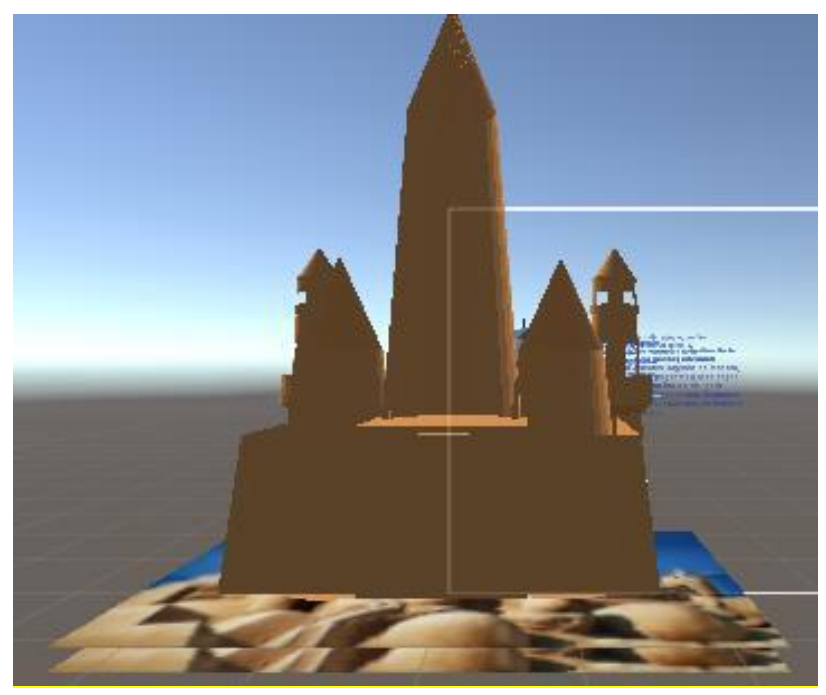

Figure 13 Object over image

A descriptive text was also added to each object, which is shown in Figure 14.

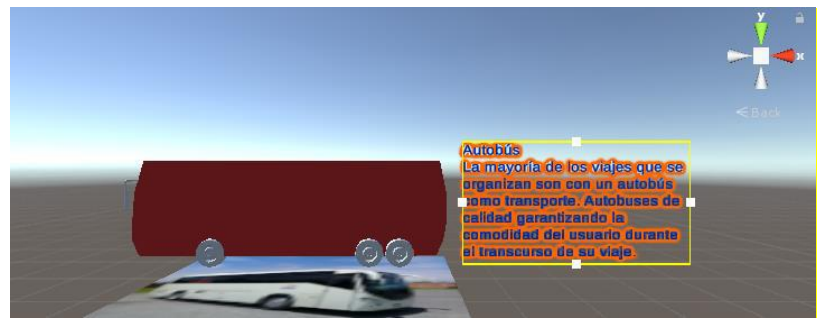

Figure 14 Descriptive text of the image

Figure 15 shows all objects related to their image and descriptive text.

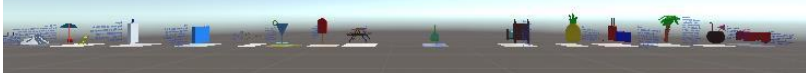

Figure 15 Objects with markers

MORA-LUMBRERAS, Marva Angélica, SÁNCHEZ-SANCHEZ, Norma and SANCHEZ-PÉREZ Carolina Rocío. Integrative activity of a point of sale and the product dissemination with augmented reality. Journal of Human Resources Training. 2019 
Finally the APK file was generated, which was installed on an Android device.

Additionally, the students made a catalog for the Augmented Reality application (Figure 16).

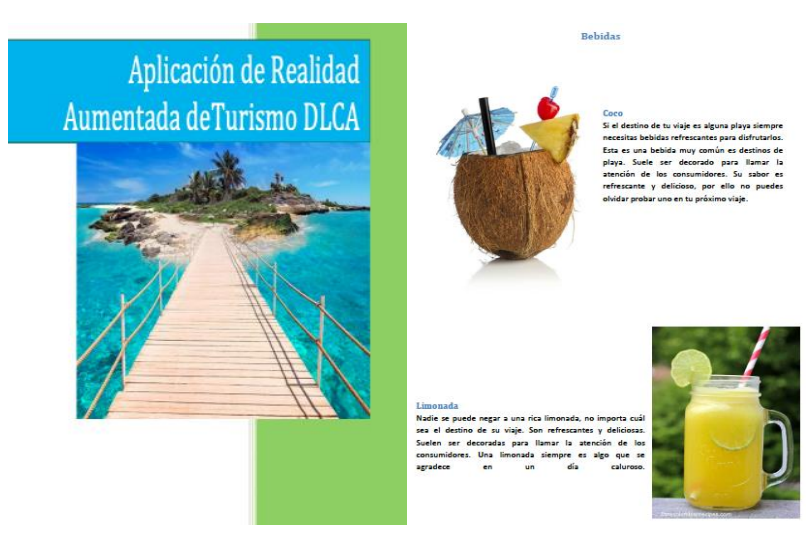

Figure 16 Tourism Point of Sale Catalog

The execution of the application is shown in Figure 17.

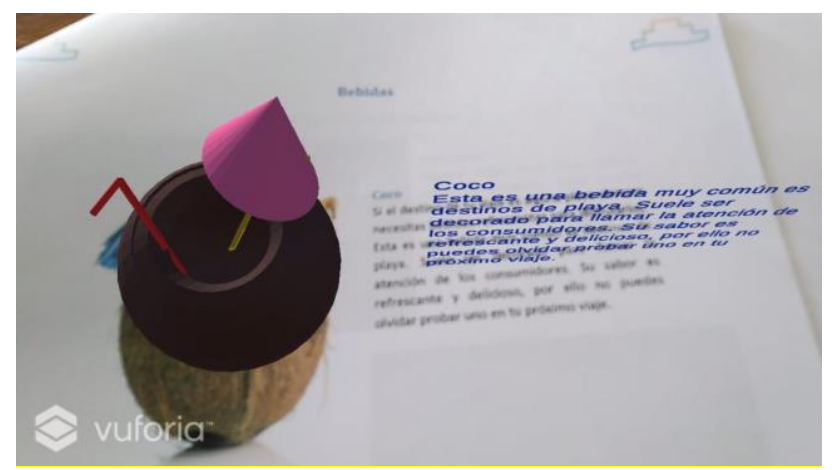

Figure 17 Augmented Reality View of a marker

\section{Discussion}

When performing for a year and a half the monitoring and implementation of the CMMi model practices, in the development of a point of sale in the educational field, it was disadvantageous that the monitoring and control activities associated with the projects are affected by the Institutional planning times, which makes timely monitoring of the project difficult, as well as the measurement of indicators associated with project planning. Even with this they were able to implement the practices of the model and verify its usefulness mainly in the testing phase. It was evidenced that the fact that the software engineering learning units functioned as an axis allowed the scope of the project not to vary and that traceability of the requirements in all the learning units was guaranteed.
During the Computer Human Interaction Paradigm Learning Unit, work was carried out according to the established planning, however, there were different controversies when requesting changes in the interface, since any change made in this learning unit should be reflected in the documentation of Software Engineering and students created some resistance to perform them, however it was satisfactorily concluded, and with this interfaces were obtained aligned to quality and design standards.

The inclusion of the Learning Unit of Design of Virtual Environments cost that will frame from the beginning, during the planning it was possible to include it with virtual worlds, but finally it was decided that the products of the Point of Sale in 3D will be modeled for dissemination, giving the possibility that the learning unit of Computing for Mobile Devices will participate with Augmented Reality.

In the Computer Learning Unit for Mobile Devices, it was determined that once the 3D product models were developed, it was most convenient to show these models through a mobile application with Augmented Reality for Android devices, and that together with a catalog that includes all the models, it would be possible to disseminate the products of the Point of Sale.

\section{Acknowledgments}

The team of Leticia Gómez Rivera, Mónica Lima Rosario, Enrique Onofre Victorero, Miriam de la Cruz Teomitzi and Cristian Salomón López Alejandro is thanked for the development of the Point of Sale for Tourism, during the exercise of the Integrative Activity.

\section{Conclusions}

During the development of the Integrative Activity, several challenges were faced, the first was to work together 6 Learning Units of the Computer Engineering career, four of them perfectly aligned, which are the three courses of Software Engineering and Interaction Paradigms Human Computer, however with two subjects it was difficult to place them from the planning, but once defined that it would work with the dissemination of the products of the Point of Sale it was believed that the problem was solved, however the Point of Sale addressed had as a tourist travel product, so it had to be coupled with products that are handled on a tourist trip.

MORA-LUMBRERAS, Marva Angélica, SÁNCHEZ-SANCHEZ Norma and SANCHEZ-PÉREZ Carolina Rocío. Integrative activity of a point of sale and the product dissemination with augmented reality. Journal of Human Resources Training. 2019 


\section{References}

CMMi Model (2010), Software Engineering Institute, Carnegie Mellon University. Fecha de última Recuperación: 1 de septiembre de 2019, enlace: https://www.sei.cmu.edu/newsevents/news/article.cfm?assetid=509086.

Chrissis Mary Beth, Konrad Mike, Shrum Sandy, CMMI® Guía para la integración de Fombona Cadavieco Javier, Pascual Sevillano María Ángeles, Madeira Ferreira, Galindo Dolores (2012), Realidad Aumentada en Museos, Social Museum.

Heras Lara Lizbeth (2007), La realidad aumentada: Una tecnología en espera de usuarios. Revista Digital Universitaria, UNAM. 10 de junio 2007, Volumen 8 Número 6, ISSN: 1067-6079.

Mass Sosa Luis Alberto, Milián Vásquez Pedro Miguel, López Ana Margarita Rodríguez del Rey, Tomé López Orlando Manuel, Vásquez Villazón Yanli, Herrera Fragoso Lázaro Roberto (2010). Las tareas docentes integradoras dentro de la estructura de la actividad de estudio Integrator Teaching Tasks within Studying Activities, Revista Electrónica de las Ciencias Médicas en Cienfuegos ISSN:1727-897X Medisur 2010; 8(6) Especial Investigación Pedagógica (Revisiones)

Peña Díaz José Antonio, Morales Molina Xiomara, Cabrera Cabrera Cristina, Anoceto Armiñana Odalis (2011), Actividades metodológicas para la preparación de facilitadores de Morfofisiología Humana en la elaboración de tareas docentes integradoras. Gaceta Médica Espirituana, Univ. Ciencias Médicas. Sancti Spiritus, Vol.13, No.2, ISSN $1608-8921$

Pérez Díaz JR. Técnicas y procedimientos para la formulación de problemas de química de la enseñanza media 2006

Preece J. Human-Computer Interaction. Wesley A, editor: Addison- Wesley, Reading, MA.; 1994.

Ratner Peter (2005), Animación 3D Diseno Y Creatividad / Design \& CreativityEditor Grupo Anaya Comercial, ISBN: 8441518092, 9788441518094.
Vásquez Sandra, Bustos Patricia, Núñez Graciela y Mazzitelli Claudia (2004), Planteo de situaciones problemáticas como estrategia integradora en la enseñanza de las ciencias y la tecnología, Revista Electrónica de Enseñanza de las Ciencias, Vol. 3, No 1, 73-85. 